\title{
Efektivitas Program Nasional Penanggulangan Kemiskinan (PNPM-Mandiri) Dalam Pengembangan Usaha Mikro Kecil Menengah (UMKM) Di Desa Lakea II Kabupaten Buol
}

\author{
${ }^{1 *}$ Nasrin Nasrin, Ermawati Ermawati ${ }^{2}$, Uswatun Hasanah ${ }^{3}$ \\ ${ }^{1}$ Jurusan Ekonomi Syariah, Fakultas Ekonomi dan Bisnis Islam, IAIN Palu \\ 2 Jurusan Ekonomi Syariah, Fakultas Ekonomi dan Bisnis Islam, IAIN Palu \\ ${ }^{3}$ Jurusan Ekonomi Syariah, Fakultas Ekonomi dan Bisnis Islam, IAIN Palu
}

ABSTRAK

Penelitian ini bertujuan untuk mengetahui sistem kerja PNPM mandiri dalam pengembangan usaha mikro kecil menengah dan efektivitas PNPM mandiri dalam pengembangan usaha mikro kecil menengah di Desa Lakea II Kec. Lakea Kab. Buol.Adapun hasil dari penelitian ini, 1) bahwa PNPM Mandiri Pedesaan menggunakan dua sistem kerja dalam pengembangan UMKM yaitu sitem pemberian langsung modal usaha serta pemberian pinjaman dana modal usaha bagi para pelaku UMKN yang ada di Desa Lakea II. Tentunya hal tersebut memiliki prosedur tersendiri untuk mendapatkan bantuan tunai secara langsung ataupun peminjaman modal usaha. Kemudian efektifitas dari pada pengembangan Usaha Mikro Menegah (UMKM) telah berjalan dengan baik, hal ini memilki dampak yang baik terhadap pelaku usaha yang ada di Desa Lakea II. Dengan adanya bantuan tunai ataupun pinajaman modal usaha sangat membantu dalam mengembangkan usaha. Dalam hal ini, pemerintah setempat memiliki peran penting dalam tercapainya tujuan yang lebih efektif dalam menjalankan sebuah program PNPM Mandri Desa Lakea II. Adapun kendala-kendala yang dihadapi oleh PNPM Mandiri Pedesaan adalah, karena masih ada beberapa pelaku usaha kurang aktif dalam mengikuti Musyawarah Antar Desa (MAD), dalam memanfaatkan pinjaman dari PNPM Mandiri Pedesaan, di karenakan para pelaku usaha berfikir bahwa untuk mendapatkan pinjaman modal usaha sama saja dengan meminjam dana di bank-bank.
INFORMASI

ARTIKEL

Kata kunci:

PNPM Mandiri, Penanggulangan, kemiskinan, Usaha mikro, usaha kecil, usaha menengah 


\section{PENDAHULUAN}

Pembangunan ekonomi di Indonesia saat ini sedang dihadapkan pada kenyataan yang masih luasnya tingkat kemiskinan terutama di pedesaan. Pada umumnya di negara yang berkembang seperti Indonesia ini masalah pendapatan rendah dan masalah kemiskinan merupakan masalah utama dalam pembangunan ekonomi. Dalam upaya meningkatkan pendapatan perkapita dari distribusi pendapatan merupakan dimensi yang perlu mendapat perhatian terutama untuk melihat tingkat pendapatan dan pembagian pendapatan diantara warga masyarakatnya. Aspek ini terkait dengan masih besarnya rakyat miskin di Indonesia, yang terutama di pedesaan. Fenomena kemiskinan perdesaan bukan merupakan suatu gejala yang baru. Secara absolut jumlah penduduk Indonesia yang masih hidup dibawah garis kemiskinan masih menunjukan angka yang relatif besar.

Pada bulan Maret 2017, jumlah penduduk miskin (penduduk dengan pengeluaran per kapita per bulan di bawah Garis Kemiskinan) di Indonesia mencapai 27,77 juta orang $(10,64$ persen), bertambah sebesar 6,90 ribu orang dibandingkan dengan kondisi September 2016 yang sebesar 27,76 juta orang $(10,70 \text { persen })^{1}$.

Indikitor pengukuran kesejahteraan masyarakat salah satunya dengan

${ }^{1}$ https://www.bps.go.id/Subjek/view/id/105 di akses pada tanggal 07 Oktober 2017 pukul 18.32 menggunakan indikator tingkat kemiskinan rumah tangga. Jika pada suatu wilayah distribusi hasil pembangunan cukup merata maka hal tersebut dapat digunakan untuk memenuhi kebutuhan masyarakat miskin. Oleh karena itu,penduduk miskin diidentikan dengan penduduk yang pendapatannya masih berada dibawah garis kemiskinan. ${ }^{2}$

Bagi masyarakat miskin yang telah memasuki usia kerja, mayoritas dari mereka berpendidikan rendah, ketrampilan yang minim serta modal yang sedikit. Salah satu jenis pekerjaan yang menjadi solusi dari permasalahn tersebut yaitu dengan bekerja atau membuka lapangan kerja di sektor Usaha Mikro dan Kecil. Sektor UMK disamping tidak memerlukan modal yang banyak, juga kurang mensyaratkan tingkat ketrampilan tenaga kerja yang tinggi sehingga UMK merupakan sektor ekonomi yang paling diminati terutama bagi masyarakat miskin.

Bagi pekerja tidak terampil dan menganggur, mikro kecil menegah dianggap sebagai pilihan yang sesuai bagi penyediaan kesempatan kerja serta untuk perolehan pendapatan. Disamping itu, mikro kecil menegah dipandang sebagai sektor yang menjanjikan bagi para pelaku wirausaha. Sektor mikro kecil menegah yang merupakan sektor

\footnotetext{
${ }^{2}$ Ninik Sudarwati. Kebijakan Pengentasan Kemiskinan: Mengurangi Kegagalan Penanggulangan Kemiskinan. (Malang: Intimedia). h. 16
} 
swasta mampu memberikan kontribusi penyerapan tenaga kerja serta pengembangan wirausaha yang tersedia dimasyarakat. ${ }^{3}$

Kegiatan perekonomian yang terdapat diperdesaan masih didominasi oleh sektor mikro kecil menegah yang meliputi pertanian, perdagangan dan industri rumah tangga. Namun demikian, para pelaku usaha masih mengalami kesulitan untuk pengembangan usaha yakni, terkendala oleh modal. Padahal modal dianggap unsur yang paling penting dalam pengembangan usaha bagimasyarakat perdesaan, keterbatasan modal menjadi penyebab kreatifitas dalam pengembangan usaha menjadi terhambat. ${ }^{4}$ Keterbatasan modal dipicu oleh lembagalembaga keuangan formal atau komersial ragu untuk mengucurkan pinjaman kepada pelaku usaha mikro kecil yang mayoritas para pelaku usaha mikro dan kecil tidak bankable atau tidak lolos pada analisis pemberian kredit. Akibatnya, sejumlah besar usaha-usaha skala kecil tidak dapat mengembangakan usahanya karena terkendala oleh modal.

Program pengentasan kemiskinan dengan konsep pemberdayaan merupakan program yang dibentuk

${ }^{3}$ Roberto Akyuwen, Krisna Wijaya, dan I Dewa Gde Suthapa. Teori dan Praktek Keuangan Mikro di Indonesia.(Yogyakarta: Penerbit Sekolah Pascasarjan UGM, 2010). h. 51

4 Hamid. Rekaman dari Seminar. Dalam Kredit Pedesaan di Indonesia. Mubyarto dan Edy Suandi Hamdi (EDS). (Yogyakarta: BPFE, 1986). oleh pemerintah. Program pemberdayaan ditujukan agar masyarakat lebih berdaya dengan melibatkan masyarakat dalam pengambilan keputusan dalam rangka pembangunan desa serta tujuan lainnya yaitu dalam pengentasan kemskinan. ${ }^{5}$

Keterlibatan masyarakat dalam pengambilan keputusan dinilai lebih efektif, karena masyarakat dianggap lebih mengetahui segala permasalahan yang dihadapai pada desa masing-masing.

PNPM Mandiri adalah program nasional penanggulangan kemiskinan berbasis pemberdayaan masyarakat yang dilaksanakan melalui program harmonisasi dan pengembangan sistem, serta mekanisme dan prosedur program, penyediaan pendampingan dan pendanaan stimulan untuk mendorong prakarsa dan inovasi masyarakat dalam upaya penanggulangan kemiskinan yang berkelanjutan. Pemberdayaan masyarakat dimaksudkan untuk menciptakan dan meningkatkan kapasitas masyarakat, baik secara individu maupun berkelompok, dalam memecahkan berbagai persolan terkait upaya peningkatan kualitas hidup, kemandirian dan kesejahteraannya. ${ }^{6}$

Salah satu kegiatan utama dari PNPM Mandiri adalah mengalokasikan Bantuan Langsung Masyarakat (BLM) untuk setiap kecamatan. Kegiatan yang

\footnotetext{
${ }^{5}$ Ninik Sudarwati. Kebijakan Pengentasan Kemiskinan: Mengurangi Kegagalan Penanggulangan Kemiskinan. (Malang: Intimedia). h. 37

6 Materi Grand Strategi Nasional PNPM Mandiri Pedesaan. (Jakarta). h.2
} 
dibiayai melaui Bantuan Langsung

Mandiri (BLM) PNPM Mandiri ditujukan untuk pembangunan infrastruktur dan program simpan pinjam untuk kelompok perempuan (SPP). Alokasi dana untuk program SPP maksimal 25 persen dari dana BLM. Tidak ada batasan alokasi maksimal per desa, namun harus mempertimbangkan hasil verifikasi kelayakan kelompok. $^{7}$

Alokasi dana yang berasal dari Bantuan Langsung Mandiri (BLM) untuk program SPP yang diperuntukkan sebagai bantuan modal kerja terhadap usaha agar masyarakat dapat meningkatkan produktivitas perekonomiannya. Disamping itu, alokasi pinjaman atau bantuan modal kerja diprioritaskan bagi masyarakat miskin yang memiliki usaha produktif.

Pengakuan Islam terhadap perbedaan alami dalam rezeki tidak berarti membiarkan orang kaya bertambah kaya dan orang miskin semakin miskin. Islam ikut campur dengan berbagai peraturan untuk memperkecil kesenjangan antara kaum kaya dan kaum miskin misalnya melalui pendistribusian zakat dengan tujuan memberikan kesempatan yang adil bagi kaum faqir untuk berdiri sejajar dengan orang-orang kaya. ${ }^{8}$

Perbedaan taraf hidup manusia adalah sebuah rahmat sekaligus pengingat

${ }^{7}$ Ibid. h. 4.

8 Yusuf Qardhawi. Peran Nilai dan Moral dalam Perekonomian Islam. (Jakarta: Robani Press). h. 437 bagi setiap kelompok manusia dengan tujuan agar bisa melengkapi satu sama lain, dalam hal ini adalah kelompok yang taraf hidupnya berkecukupan atau lebih berdaya dapat membantu dengan kelompok yang kurang mampu sehingga akan menciptakan interaksi sosial dimasyarakat.

Pendistribusian harta bertujuan agar harta tersebut tidak beredar diantara orang-orang yang mampu saja. Sarana Islam dalam merealisasikan hal tersebut ialah mengupayakan peningkatan taraf hidup kaum faqir dengan pemberdayaan. Konsep Islam dalam melakukan pendistribusian tidak hanya sebatas memberikan bantuan berupa harta yang dimiliki, melainkan bagaimana modal tersebut dipergunakan secara produktif, salah satu contoh adalah implementasi zakat produktif.

Desa Lakea II Kecamatan Lakea merupakan salah satu kecamatan di Kabupaten Buol yang memiliki jumlah keluarga miskin yang cukup besar. Dilihat dari tingkat kesejahteraan masyarakat, Desa Lakea II Kecamatan Lakea menghadapi persoalan yang cukup kompleks berkenaan dengan kemiskinan atau penyandang masalah kesejahteraan sosial. Sebagai berikut merupakan klasifikasi rumah tangga miskin dan rumah tangga pada masingmasing desa tahun 2009 - 2010 di Desa Lakea II Kecamatan Lakea. 
Gambaran tersebut menunjukkan bahwa masalah kesejahteraan sosial penduduk masing-masing desa merupakan masalah yang perlu mendapatkan perhatian dari pemerintah dan masyarakat. Sehingga program pemberdayaan masyarakat seperti PNPM Mandiri Pedesaan sangat dibutuhkan, dengan maksud agar tujuan dari program tersebut dapat terlaksana.

\section{TINJAUAN PUSTAKA}

\subsection{Penelitian Terdahulu}

Penelitian Indrajaya (2009) dengan judul penelitian Efektivitas pelaksanaan Program Nasional Pemberdayaan Masyarakat Mandiri Perdesaan (PNPM-MP) di Kecamatan Kuta berkesimpulan mengenai dampak pelaksanaan program PNPM Mandiri Perdesaan terhadap peningkatan pendapatan dan kesempatan kerja masyarakat miskin di Kecamatan Kuta yaitu : adanya peningkatan pendapatan dan peningkatan kesempatan kerja sesudah menerima program dibandingkan sebelum menerima program PNPM Mandiri Perdesaan. Dalam penelitiannya yang menjadi sampel penelitian adalah seluruh populasi rumah tangga miskin (RTM) yang ada di Kecamatan Kuta berdasarkan hasil pendataan BPS Kabupaten Tapanuli Selatantahun 2008 yaitu sebanyak 115 rumah tangga.
Selanjutnya Haris (2010) dengan judul penelitiannya Efektivitas Pelaksanaan Program Nasional Pemberdayaan Masyarakat Mandiri Perdesaan (PNPM-MP) di Desa Pulo Dogom Kecamatan Kualuh Hulu Kabupaten Labuhan Batu Utara. Efektivitas pelaksanaan kegiatan simpan pinjam perempuan dalam penelitian ini, dilihat melalui 4 indikator, yaitu : tingkat kualitas, tingkat kuantitas, tingkat dampak dan tingkat waktu. Penelitiannya ini adalah penelitian deskriptif, dimana sampel dalam penelitian ini adalah semua anggota dari dua kelompok simpan pinjam perempuan, yaitu sebanyak 40 orang. Instrumen analisa data yang digunakan adalah kuesioner, wawancara, serta tabulasi data yang tertuang dalam tabel data tunggal. Analisa data yang dilakukan, maka diperoleh hasil bahwa Kegiatan Simpan Pinjam Perempuan di Desa Pulo Dogom belum efektif. Hal itu terlihat dari 4 indikator dalam melihat efekktivitas suatu kegiatan, yaitu terdiri dari : tingkat kualitas, dimana anggota kelompok kurang mudah untuk mendapatkan pendanaan dan pengembalian angsuran pinjaman. Tingkat kuantitas, dilihat dari modal yang diterima masih kurang dalam pembagian yang tidak merata kepada anggota kelompok dan penghasilan hanya bertambah sedikit dikarenakan anggota yang membuka usaha dengan modal sendiri yang jumlahnya lebih besar dari pada modal yang diberikan oleh 
PNPM-MP. Tingkat dampak, dilihat dari jenis usaha yang dilakukan sebelum dan setelah mengikuti kegiatan, jenis usaha tidak ada yang berubah menjadi usaha yang lebih besar, melainkan hanya terhadap penghasilan anggota kelompok yang berpengaruh. Tingkat waktu, dilihat dari pelaksanaan kegiatan simpan pinjam perempuan sebagian besar anggota membutuhkan waktu diatas 2 tahun untuk dapat menunjukkan hasil. Dari penelitian yang dilakukan, maka penulis dapat menyimpulkan bahwa kegiatan simpan pinjam perempuan dari PNPM-MP ini adalah program yang belum efektif bagi kelompok masyarakat, dan dalam pengentasan kemiskinan.

\subsection{Program Penanggulangan Kemiskinan}

Beberapa program yang tengah digalakkan oleh pemerintah dalam menanggulangi kemiskinan antara lain dengan memfokuskan arah pembangunan pada tahun 2008 pada pengentasan kemiskinan. Fokus program tersebut meliputi 5 hal antara lain pertama menjaga stabilitas harga bahan kebutuhan pokok; kedua mendorong pertumbuhan yang berpihak pada rakyat miskin; ketiga menyempurnakan dan memperluas cakupan program pembangunan berbasis masyarakat; keempat meningkatkan akses masyarakat miskin kepada pelayanan dasar; dan kelima membangun dan menyempurnakan sistem perlindungan sosial bagi masyarakat miskin.

Dari 5 fokus program pemerintah tersebut, diharapkan jumlah rakyat miskin yang ada dapat tertanggulangi sedikit demi sedikit. Beberapa langkah teknis yang digalakkan pemerintah terkait 5 program tersebut antara lain:

1. Menjaga stabilitas harga bahan kebutuhan pokok. Fokus program ini bertujuan menjamin daya beli masyarakat miskin/keluarga miskin untuk memenuhi kebutuhan pokok terutama beras dan kebutuhan pokok utama selain beras. Program yang berkaitan dengan fokus ini seperti :

a. Penyediaan cadangan beras pemerintah 1 juta ton

b. Stabilisasi/kepastian harga komoditas primer

2. Mendorong pertumbuhan yang berpihak pada rakyat miskin. Fokus program ini bertujuan mendorong terciptanya dan terfasilitasinya kesempatan berusaha yang lebih luas dan berkualitas bagi masyarakat/keluarga miskin. Beberapa program yang berkenaan dengan fokus ini antara lain:

a. Penyediaan dana bergulir untuk kegiatan produktif skala usaha mikro dengan pola bagi hasil/syariah dan konvensional. 
b. Bimbingan teknis/pendampingan dan pelatihan pengelola Lembaga Keuangan Mikro (LKM)/Koperasi Simpan Pinjam (KSP).

c. Pelatihan budaya, motivasi usaha dan teknis manajeman usaha mikro

d. Pembinaan sentra-sentra produksi di daerah terisolir dan tertinggal

e. Fasilitasi sarana dan prasarana usaha mikro.

f. Pemberdayaan ekonomi masyarakat pesisir.

g. Pengembangan usaha perikanan tangkap skala kecil.

h. Peningkatan akses informasi dan pelayanan pendampingan pemberdayaan dan ketahanan keluarga.

i. Percepatan pelaksanaan pendaftaran tanah.

j. Peningkatan koordinasi penanggulangan kemiskinan berbasis kesempatan berusaha bagi masyarakat miskin.

3. Menyempurnakan dan memperluas cakupan program pembangunan berbasis masyarakat. Program ini bertujuan untuk meningkatkan sinergi dan optimalisasi pemberdayaan masyarakat di kawasan perdesaan dan perkotaan serta memperkuat penyediaan dukungan pengembangan kesempatan berusaha bagi penduduk miskin. Program yang berkaitan dengan fokus ketiga ini antara lain :

a. Program Nasional Pemberdayaan Masyarakat (PNPM) di daerah perdesaan dan perkotaan

b. Program Pengembangan Infrastruktur Sosial Ekonomi Wilayah.

c. Program Pembangunan Daerah Tertinggal dan Khusus.

d. Penyempurnaan dan pemantapan program pembangunan berbasis masyarakat.

4. Meningkatkan akses masyarakat miskin kepada pelayanan dasar. Fokus program ini bertujuan untuk meningkatkan akses penduduk miskin memenuhi kebutuhan pendidikan, kesehatan, dan prasarana dasar. Beberapa program yang berkaitan dengan fokus ini antara lain :

a. Penyediaan beasiswa bagi siswa miskin pada jenjang pendidikan dasar di Sekolah Dasar (SD)/Madrasah Ibtidaiyah (MI) dan Sekolah Menengah Pertama (SMP)/Madrasah Tsanawiyah (MTs);

b. Beasiswa siswa miskin jenjang Sekolah Menengah Atas/Sekolah Menengah Kejuruan/Madrasah Aliyah (SMA/SMK/MA);

c. Beasiswa untuk mahasiswa miskin dan beasiswa berprestasi; 
d. Pelayanan kesehatan rujukan bagi keluarga miskin secara cuma-cuma di kelas III rumah sakit;

5. Membangun dan menyempurnakan sistem perlindungan sosial bagi masyarakat miskin. Fokus ini bertujuan melindungi penduduk miskin dari kemungkinan ketidakmampuan menghadapi guncangan sosial dan ekonomi. Program teknis yang di buat oleh pemerintah seperti :

a. Peningkatan kapasitas kelembagaan pengarusutamaan gender (PUG) dan anak (PUA).

b. Pemberdayaan sosial keluarga, fakir miskin, komunitas adat terpencil, dan penyandang masalah kesejahteraan sosial lainnya.

c. Bantuan sosial untuk masyarakat rentan, korban bencana alam, dan korban bencana sosial.

d. Penyediaan bantuan tunai bagi rumah tangga sangat miskin (RTSM) yang memenuhi persyaratan (pemeriksaan kehamilan ibu, imunisasi dan pemeriksaan rutin BALITA, menjamin keberadaan anak usia sekolah di SD/MI dan SMP/MTs; dan penyempurnaan pelaksanaan pemberian bantuan sosial kepada keluarga miskin/RTSM) melalui perluasan Program Keluarga Harapan (PKH). e. Pendataan pelaksanaan PKH (bantuan tunai bagi RTSM yang memenuhi persyaratan). ${ }^{9}$

\subsection{Strategi Penanggulangan Kemiskinan menurut Al-Qur'an}

Problematika sosial yang kita hadapi di dunia ini, yang salah satunya adalah kemiskinan ini telah diwanti-wanti oleh alQur'an. Sehingga sebenarnya al-Qur'an telah melakukan tindakan preventif agar tidak terjadi kemiskinan yang bergitu luas di kalangan penduduk bumi ini.

Kemiskinan ini sangatlah berbahaya, baik untuk diri sendiri maupun untuk agama kita tercinta Islam. Berapa banyak orangorang yang pindah agama lain Karena mie instan satu kardus. Bahkah, demi menyambung hidup mereka rela mengorbankan akidah. Inilah bahayanya penyakit yang dinamakan kemiskinan. Sampai-sampai Rasulullah SAW bersabda:

$$
\text { كَادَ الْفَعْرُ أَنْ يَكُوْنَ كُفْرًا (الحديث) }
$$

Artinya :

Hampir saja kefakiran itu menyebabkan kepada kekufuran (alHadits)

\footnotetext{
Muhammad Hambali, https://marx83.wordpress.com/2008/07/05/upaya penanggulangan-kemiskinan/. Diakses pada 02 Juli 2017, jam 20.33 wita.
} 
Maka dari itu, al-Qur'an telah memberikan beberapa strategi/langkahlangkah untuk menanggulangi kemiskinan ini, di antaranya:

\section{Al-Qur'an menyeru untuk bekerja dan} berusaha

Allah SWT melarang kita untuk hidup bermalas-malasan. Bahkan Allah SWT memerintahkan kita untuk selalu giat bekerja dan berusaha. Bertebaran di muka bumi ini untuk mencari rizki Allah SWT. Hal ini disebabkan Allah SWT telah menyebarkan rizki itu dari berbagai sumber yang kita tidak tahu dari sumber yang mana rizki kita itu. Dengan tegas, Allah SWT memerintahkan manusia untuk bertebaran di muka bumi ini mencari fadlillah (rizki)

\section{Konsep Pemberdayaan Masyarakat}

Kartasasmita menyatakan bahwa memberdayakan masyarakat adalah upaya untuk meningkatkan harkat dan martabat lapisan masyarakat yang dalam kondisi sekarang tidak mampu melepaskan diri dari perangkap kemiskinan dan keterbelakangan. Dengan perkataan lain memberdayakan masyarakat adalah memampukan dan memandirikan masyarakat. Upaya yang dapat dilakukan dengan tiga langkah:

a. Menciptakan suasana atau iklim yang memungkinkan masyarakat untuk berkembang (enabling). b. Memperkuat potensi alat daya yang dimiliki masyarakat(empowering).

c. Melindungi (protecting). ${ }^{10}$

\section{Strategi Pemberdayaan Masyarakat}

Strategi pada umumnya mempunyai tiga arah yaitu:

a. Pemihakan dan pemberdayaan masyarakat miskin (pro-poor).

b. Pemantapan otonomi dan pendelegasian wewenang dalam pengelolaan pembangunan didaerah yang mengembangkan peran serta masyarakat.

c. Modernisasi melalui penajaman dan pemantapan arah perubahan struktur sosial ekonomi dan budaya yang bersumber pada peran serta masyarakat lokal.

\section{Langkah Pemberdayaan Masyarakat}

Moeljarto mengatakan bahwa ada beberapa langkah dalam pemberdayaan masyarakat miskin:

a. Pemberdayaan masyarakat merupakan prasyarat bagi upaya penanggulangan kemiskinan. Langkah konkrit adalah meningkatkan kesadaran kritis masyarakat atas posisinya dalam struktur sosial politik dimana orang miskin itu tinggal.

b. Upaya memutuskan hubungan yang bersifat eksploitatif terhadap lapisan orang miskin, artinya membiarkan kesadaran kritis orang miskin muncul untuk melakukan reorganisasi dalam

\footnotetext{
${ }^{10}$ Ginanjar, Kartasasmita, Pembangunan Untuk Rakyat: MemadukanPertumbuhan Dan Pemerataan. (Jakarta: Pustaka Cidesindo. 1996). h. 18.
} 
rangka meningkatkan produktivitas kerja dan kualitas hidupnya.

c. Menanamkan rasa kebersamaan dan memberikan gambaran bahwa kemiskinan bukan merupakan takdir tetapi penjelmaan konstrusi sosial.

$d$. Merealisasi perumusan pembangunan dengan melibatkan masyarakat miskin secara penuh.

$e$. Perlunya pembangunan sosial dan budaya bagi masyarakat miskin.

$f$. Perlunya kontribusi prasarana pembangunan yang lebih merata. ${ }^{11}$

\subsection{Konsep PNPM Mandiri Perdesaan}

Mulai tahun 2007 pemerintah Indonesia mencanangkan programnasional pemberdayaan masyarakat mandiri perdesaan (PNPM Mandir Perdesaan). PNPM Mandiri perdesaan adalah program untuk mempercepat penanggulangan kemiskinan secara terpadu dan berkelanjutan. PNPM Mandiri perdesaan merupakan kelanjutan Program Pengembangan Kecamatan (PPK), yang selama ini dinilai berhasil. Diantara keberhasilan PPK adalah penyediaan penyediaan lapangan kerja dan pendapatan bagi kelompok rakyat miskin, efisiensi dan efektivitas kegiatan,dan keberhasilannya menumbuhkan kolektivitas dan partisipasi masyarakat.

Visi PNPM Mandiri perdesaan

\footnotetext{
${ }^{11}$ Moeljarto. Pemberdayaan Masyarakat. (Jakarta: Rineka Cipta, 1993). h. 34.
}

Tercapainya kesejahteraan dan kemandirian masyarakat miskin perdesaan. Kesejahteraan berarti terpenuhinnya kebutuhan dasar masyarakat, kemandirian berarti mampu mengorganisir diri untuk memobilisasi sumber daya yang ada dilingkungannya, mampu mengentaskan sumber daya di luar lingkungannya, serta mengelola sumber daya tersebut untuk mengatassi masalah kemiskinan.

Misi PNPM Mandiri perdesaan adalah:

1) Peningkatan kapasitas masyarakat dan kelembagaannya

2) Pelembagaan sistem pembangunan partisipatif

3) Pengefektifan fungsi dan peran pemerintah lokal

4) Peningkatan kualitas dan kuantitas prasaran sarana sosial sosial dan ekonomi masyarakat

5) Pengembangan jaringan kemitraan dalam pembangunan. ${ }^{12}$

Dalam rangka mencapai visi dan misi PNPM Mandiri Perdesaan, strategi yang dikembangkan PNPM Mandiri Perdesaan yaitu menjadikan Rumah Tangga Miskin (RTM) sebagai kelompok sasaran, menguatkan sistem pembangunan partisipatif, serta mengembangkan kelembagaan kerja sama antar desa. Berdasarkan visi misi strategi yang dikembangkan, maka PNPM Mandiri

\footnotetext{
${ }^{12}$ PTO Program Nasional Pemberdayaan Masyarakat (PNPM)Mandiri Perdesaan.Jakarta: Departemen Dalam Negeri RepublikIndonesia. 2008. h. 2.
} 
Perdesaan lebih menekankan pentingnya pemberdayaan sebagai pendekatan yang dipilih. Melalui PNPM Mandiri Perdesaan diharapkan masyarakat dapat menuntaskan tahapan pemberdayaan yaitu tercapainya kemandirian dan berkelanjutan, setelah tahapan pembelajaran dilakukan melalui Program Pengembangan Kecamatan (PPK).

Tujuan umum PNPM Mandiri Perdesaan adalah meningkatkannya kesejahteraan dan kesempatan kerja masyarakat miskin di perdesaan dengan mendorong kemandirian dalam pengambilan keputuasan pengelolaan pembangunan.Tujuan khususnya meliputi: 1) Meningkatkan partisipasi seluruh masyarakat, khususnya masyarakat miskin dan atau kelompok perempuan, dalam pengambilan keputusan perencanan, pelaksanaan, pemantauan dan pelestarian pembangunan.

2) Melembangakan pengelolaan pembangunan partisipatif dengan mendayagunakan sumber daya lokal

3) Mengembangkan kapasitas pemerintah desa dalam memfasilitasi pengelolaan pengelolaan pembangunan partisipaif

4) Menyediakan prasarana sarana sosial dasar dan ekonomi yang diprioritaskan oleh masyarakat

5) Melembagakan pengelolaan dana bergulir.
6) Melembagakan terbentuknya dan berkembangnya Badan Kerjasama Antar Desa (BKAD)

7) Mengembangkan kerjasama antar pemangku kepentingan dalam upaya penanggulangan kemiskinan perdesaan. ${ }^{13}$

\section{Prinsip dasar PNPM Mandiri Perdesaan}

Sesuai dengan pedoman umum, PNPM Mandiri Perdesaan mempunyai prinsip atau nilai-nilai dasar yang selalu menjadi landasan atau acuan dalam setiap pengambilan keputusan maupun tindakan yang akan diambil dalam pelaksanaan rangkaian kegiatan PNPM Mandiri Perdesaan. Nilai-nilai dasar tersebut diyakini mampu mendorong terwujudnya tujuan PNPM Mandiri Perdesaan. Prinsipprinsip tersebut meliputi:

1) Bertumpu pada pembangunan manusia. Pengertian prinsip bertumpu pada pembangunan manusia adalah masyarakat hendaknya memilih kegiatan yang berdampak langsung terhadap upaya pembangunan manusia dari pada pembangunan fisik semata.

2) Otonomi. Pengertian prinsip otonomi adalah masyarakat memiliki hak dan kewenangan mengatur diri secara

\footnotetext{
${ }^{13}$ Pedoman Umum Program Nasional Pemberdayaan Masyarakat(PNPM) Mandiri Tahun 2007. Jakarta: Departemen Dalam NegeriRepublik Indonesia. 2007. h. 11.
} 
mandiri dan bertanggung jawab tanpa intervensi negative dari luar.

3) Desentralisasi. Pengertian prinsip desentralisasi adalah memberikan ruang yang lebih luas kepada masyarakat untuk mengelola kegiatan pembangunan sektoral dan kewajiban yang bersumber dari pemerintah dan pemerintah daerah sesuai dengan kapasitas masyarakat.

4) Berorientasi pada masyarakat miskin. Pengertian prinsip berorientasi pada masyarakat miskin adalah segala keputusan yang diambil berpihak pada masyarakat miskin.

5) Partsipasi. Pengertian prinsip partisipasi adalah masyarakat berperan secara aktif dalam proses atau alur tahapan program dan pengawasan, mulai dari tahapan sosial, perencanan, pelaksanaan dan pelestarian kegiatan dengan memberikan sumbangan tenaga, pikiran atau dalam bentuk materil.

6) Kesetaraan dan keadilan gender. Pengertian prinsip kesetaraan dan keadilan gender adalah masyarakat baik laki-laki dan perempuan mempunyai kesetaraan dalam perananya disetiap tahapan program dan dalam menikmati manfaat kegiatan pembangunan, kesetaraan juga dalam pengertian kesejajaran kedudukan pada saat situasi konflik.

7) Demokrasi. Pengertian prinsip demokrasi adalah masyarakat mengambil keputusan pembangunan secara musyarawarah dan mufakat.

8) Transparansi dan akuntabel. Pengertian prinsip transparansi dan akuntabel adalah masyarakat memiliki akses terhadap segala informasi dan proses pengambilan keputusan sehingga penggelolaan kegiaan dapat dilaksanakan secara terbuka dan dapat dipertanggungjawabkan baik secara moral, teknis, legal maupun administratif.

9) Prioritas. Pengertian prinsip prioritas adalah masyarakat memilih kegiatan yang diutamakan dengan mempertimbangkan kemendesakan dan kemanfaatan untuk pengentasan kemiskinan.

10) Keberlanjutan. Pengertian prinsip keberlanjutan adalah bahwa dalam setiap pengambilan keputuasan atau tindakan pembangunan, mulai dari tahap perencanaan, pelaksanaan, pengendalian dan pemeliharaan kegiatan harus telah mempertimbangkan sistem pelestarian. $^{14}$ 


\section{METODE PENELITIAN}

Pendekatan yang digunakan dalam penelitian ini adalah penelitian kualitatif. Bogdan dan Taylor mendefinisikan penelitian kualitatif sebagai penelitian yang menghasilkan data deskriptif berupa katakata tertulis atau lisan dari orang-orang dan perilaku yang dapat diamati. ${ }^{15}$

Dengan digunakan metode kualitatif ini maka data yang didapatkan akan lebih lengkap, lebih mendalam, kredibel, dan bermakna, sehingga tujuan penelitian dapat dicapai. Desain penelitian kualitatif ini dibagi dalam empat tahap yaitu perencanaan, pelaksanaan, analisis, dan evaluasi. Dalam penelitian kualitatif tidak dikenal istilah populasi dan sampel. Istilah yang digunakan adalah setting atau tempat penelitian. lokasi penelitiannya adalah di Desa Lakea II Kec. Lakea Kab. Buol.

Data dikumpul melalui teknik observasi langsung, wawancara mendalam, dan data yang bersumber dari dokumen. Kemudian data di analisis melalui tahapan reduksi, penyajian, dan verifikasi melalui teknik trianggulasi.

Triangulasi teknik dalam pengujian kredebilitas data dilakukan dengan cara mengecek data kepada sumber yang sama dengan teknik yang berbeda. Misalanya data diperoleh dengan wawancara

${ }^{15}$ Lexy J.Moleong, Metodologi Penelitian Kualitatif, (Bandung,: Remaja Rosdakarya, 2002) h. 9. akan dicek dengan teknik observasi, dokumentasi. Bila dengan berbagai teknik pengujian kredibilitas data tersebut menghasilkan data yang berbeda-beda, maka peneliti melakukan diskusi lebih lanjut kepada sumber data yang bersangkutan atau yang lain, untuk memastikan yang dianggap benar.

\section{HASIL DAN PEMBAHASAN}

\subsection{Gambaran objek penelitian}

PNPM Mandiri di Desa Lakea II Kecamatan Lakea ini, mulaiberoperasi sejak tahun 2008 sampai Tahun 2015. Adapun kegiatan yang dilakukansemuanya merujuk kepada Petunjuk Teknis Operasional (PTO) yang telah diaturlangsung dari PNPM Mandiri Pedesaan Pusat. Bentuk program yang telahdilaksanakan adalah pembangunan inprastruktur, pemberian pengembangan usaha, dan simpanpinjam.

Dalam rangka mencapai visi dan misi Program Nasional Pemberdayaan Masyarakat Mandiri Perdesaan yaitu menjadikan masyarakat miskin sebagai kelompok sasaran, menguatkan sistem pembangunan partisipatif, serta mengembangkan kelembagaan kerja sama antar desa. Berdasarkan visi, misi dan strategi yang dikembangkan, maka Program Nasional Pemberdayaan Masyarakat Mandiri Perdesaan lebih menekankan pentingnya 
pemberdayaan sebagai pendekatan yang dipilih.

Melalui Program Nasional

Pemberdayaan Masyarakat Mandiri

Perdesaan diharapkan masyarakat dapat menuntaskan tahapan pemberdayaan yaitu tercapainya kemandirian dan keberlanjutan, setelah tahapan pembelajaran dilakukan melalui Program Pengembangan Kecamatan.

\subsection{Sistim Kerja PNPM Mandiri}

Indonesia memiliki persoalan kemiskinan dan pengangguran. Kemiskinan danpengangguran ini lebih dipicu oleh rendahnya kesempatan kerjabagi angkatan kerjadi pedesaan. Upaya untuk menanggulanginya harus menggunakan pendekatan multidisiplin yang berdimensi pemberdayaan. Sejalan dengan itu, pemerintah Indonesiatelah mencanangkan Program Nasional Pemberdayaan Masyarakat (PNPM) Mandiri.PNPM Mandiri ini ada beberapa macam, diantaranya PNPM Mandiri Pedesaan, PNPM Mandiri Perkotaan, dan lainnya.

PNPM Mandiri Pedesaan adalah program yang dicanangkan pemerintah untukmempercepat penanggulangan kemiskinan secara terpadu dan berkelanjutan.ProgramNasional Pemberdayaan Masyarakat (PNPM)Mandiri
Pedesaandi Desa Lakea II ini mulai beroperasi tahun 2007. ${ }^{16}$

Bagimasyarakat khusunya para pelaku UMKM, mereka sangat merasakan betul manfaatdari program-program PNPM Mandiri ini, terutama untuk program dari dana yangdipinjamkan oleh PNPM Mandiri Pedesaan ini.

Sementara itu bentuk sistem kerja yang di terapkan oleh PNPM Mandiri Desa Lakea II dalam meningkatkan UMKM yang ada di Desa Lakea II yaitu dengan menggunakan sebuah sistem kerja berbasis pemberian bantuan usaha sesuai dengan kriteria yang ada serta menggunakan sistem simpan pinjam melalui koperasi yang ada pada PNPM Mandiri Desa Lakea II. Hal tersebut sebagaimana diakatakan oleh Ibu Wati Selaku UPK PNPM Mandiri Desa Lakea II, yang berhasil peneliti wawancarai di kediaman beliau mengatakan :

Bahwa dalam sistem kerja yang dilakukan oleh PNPM Mandiri Desa Lakea II dalam hal ini pengembangan Usaha Mikro Kecil Menegah yang ada di Desa Lakea II, yaitu dengan menggunakan sebuah sistem pemberian bantuan Usaha kepada masyarakat yang memenuhi ketentuanketentuan yang ada di PNPM Mandiri, sedangkan ada pula sistem yang digunakan yaitu sebuah sistem kerja melalui program simpan pinjam pada

${ }^{16}$ Wati, UPK PNPM Mandiri Desa Lakea II Kecamatan Lakea. Wawancara, pada tanggal 19 Agustus 2017. 
koperasi PNPM Mandiri di Desa Lakea II. ${ }^{17}$

Dengan demikian, dapat disimpulkan bahwa sistem kerja yang dilaksanakan oleh PNPM Mandiri Desa Lakea II, dalam hal inin guna meningkatkan UMKM yang ada sangatlah membantu dalam pengembangan usaha yang dimiliki oleh masyarakat di Desa Lakea II

Hal ini pula diungkapkan oleh salah satu pemerintah Desa yang ada di Desa Lakea II, mengungkapkan bahwa :

Dengan adanya program PNPM Mandiri tentuya sangat membantu dalam meningkatkan sebuah perekonomian yang ada di Desa Lakea II, dalam hal ini bagi masyarakat yang memiliki usaha tetapi dalam mengembangkan usaha tersebut terkadang mereka mendapat kendala dalam segi permodalan. Tentunya dengan adanya sebuah program kerja atau sistem kerja yang ada di PNPM Mandiri khususnya dalam pengembangan sebuah usaha tentunya sangat membantu utnuk pengembangan usaha mereka. Tentunya pemerintah dalam hal ini mendukung sepenuhnya atas programprogram yang ada di PNPM Mandiri terutama dalam menuntaskan kemiskinan Masyarakat saat ini. ${ }^{18}$

Dapat disimpulkan bahwa dalam hal ini pemerintah Desa Lakea II sangatlah mendukung bahkan bersyukur dengan adanya program pengembangan UMKM

17 Wati, UPK PNPM Mandiri Desa Lakea II Kecamatan Lakea,.Wawancara, pada tanggal 19 Agustus 2017.

${ }^{18}$ Kamarudin Datuatan, Sekretaris Desa Lakea II, Wawancara, pada tanggal 20 Agustus 2017 yang dilaksanakan oleh PNPM Mandiri Desa Lakea II dalam hal ini untuk mengembangkan sebuah usaha yang dilakoni oleh masyarakat Desa Lakea II.

\subsection{Efektivitas PNPM Mandiri Dalam Pengembangan Usaha Mikro Kecil Menengah}

Efektivitas merupakan unsur pokok untukmencapai tujuan atau sasaran yang telah ditentukan didalam setiap organisasi,kegiatan ataupun program.Disebut efektif apabila tercapai tujuan ataupun sasaranseperti yang telah ditentukan. Secara singkat,Efektivitas adalah pengukuran dalam arti tercapainyatujuan yang telah ditentukan sebelumnya. Selanjutnya,dijelaskan oleh Steers, bahwa :

Efektivitas adalahjangkauan usaha suatu program sebagai suatu sistemdengan sumber daya dan sarana tertentu untukmemenuhi tujuan dan sasarannya tanpa melumpuhkancara dan sumber daya itu serta tanpa memberi tekananyang tidakwajar terhadap pelaksanaannya. ${ }^{19}$

Pemberdayaan Usaha Mikro Kecil danMenengah (UMKM) dalam Program PengembanganPemberdayaan Masyarakat disesuaikan denganpotensi, permasalahan dan karakteristik yang sesuaidengan program

\footnotetext{
${ }^{19}$ http://journal.unair.ac.id/downloadfullpapers $16 \% 20$ Baktiar_KMP\%20V1\%20N1\%20Jan -April\%202013.pdf diakses pada tanggal 23 Agustus 2017., jam 20.33 Wita.
} 
pemberdayaan Mikro Kecil danMenengah (UMKM) kawasan industri/Usaha kecil dan menengah. Pemberdayaan bagi masyarakat sangatlahpenting (termasuk UMKM).

Dalam hal ini dengan adanya pemberian bantuan terhadap peningkatan UMKM yang ada di Desa Lakea II, bertujuan untuk meningkatkan perekonomian masyarakat. Tentunya dalam hal ini para masyarakat yang manjalankan sebuah usaha kecil yang ada di Desa Lakea II.

Sebagaimana yang dijelaskan oleh Sekretaris PNPM Mandiri Desa Lakea II, yang berhasil peneliti wawancarai mengatakan bahwa :

Pada pemberian bantuan usaha terhadap masyarakat itu bertujuan untuk agar dapat meningkatkan sebuah usaha serta perekonomian bagi masyarakat yang manjalankan UMKM di Desa Lakea II dalam hal ini pengembangan usaha mikro kecil menegah. Hal ini terbukti hampir $90 \%$ bahwa dengan di berikan bantuan usaha melalui program PNPM Mandiri Desa Lakea II berdampak positif bagi para pengusaha mikro kecil dan menengah yang ada di Desa Lakea II. ${ }^{20}$

Dengan demikian tentunya dengan pemberian bantuan modal kepada para pelaksana UMKM di Desa Lakea II, akan terus di pantau sejauh mana efektifitas dari pada pemberian bantuan tersebut, karena hal ini tentunya dapat berdampak pada peningkatan ekonomi masyarakat Desa Lakea II dalam mengembangkan sebuah usaha, serta dapat membantu mengetaskan kemiskinan pada masyarakat.

Tentu hal ini tidak bisa lepas dari pantauan pemerintah setempat khususnya bagi pemerintah Desa Lakea II, untuk mengawasi sudah sejauh mana perkembangan atau efektifitas terhadap pemberian sebuah bantuan usaha dalam hal ini pelaksana UMKM di Desa Lakea II. Hal ini seperti yang diungkapkan oleh Kepala Desa Lakea II yang berhasil peneliti wawancarai di Kantor Desa Lakea II mengatakan bahwa :

Sejauh ini pemerintah desa selalu memantau perkembangan dari pada pemberian modal usaha kepada masyarakat pelaksana UMKM, sehingga berjalan lebih efektif dalam mengelola modal bantuan usaha yang diberikan oleh PNPM Mandiri, hal ini pula tidak jauh berbeda dengan pemberian pinjaman modal usaha bagi masyarakat lainnya. $^{21}$

Dengan adanya peran aktif pemerintah setempat khususnya dalam hal ini pemerintah Desa Lakea II, dalam mengawasi pemberian modal usaha terhadap pengguna UMKM yang ada di masyarakat Desa Lakea II dapat memberikan dampak

${ }^{20}$ Syahrianto, Sekretaris PNPM Mandiri Desa Lakea II Kecamatan Lakea, Wawancara, pada tanggal 21 Agustus 2017
21 Aluy N Samawati, Kepala Desa Lakea II, Wawancara, pada tanggal 21 Agustus 2017 
positif tersendiri dalam mengelola lebih efektif penggunaan modal usaha tersebut.

Sejauh ini dari hasil penelitian yang peneliti lakukan terhadap efektifitas yang PNPM Mandiri dalam mengembangkan Usaha Mikro Kecil Menegah yang ada di Desa Lakea II, berjalan efektif sesuai dengan keinginan pemerintah serta sesuai dengan program yang dijalankan oleh PNPM Mandiri yang ada di Desa Lakea II, yaitu mengentaskan kemiskinan serta memberikan pengembangan usaha terhadap masyarakat.

Hal tersebut seperti yang diungkapkan oleh salah satu penerima bantuan modal usaha mengatakan bahwa :

Dengan adanya bantuan modal usaha yang diberikan oleh PNPM Mandiri Desa Lakea II, alhamdulillah sangat membantu dalam mengembangkan sebuah usaha yang saya jalani saat ini. Tentunya Saya berharap pemerintah dapat terus memperhatikan masyarakat yang memiliki usaha kecil-kecilan atau yang sudah mulai berkembang, agar dapat meningkatkan perekonomian masyarakat Inodnesia. ${ }^{22}$

Dengan demikian dapat disimpulkan bahwa, dengan adanya bantuan modal usaha tersebut sangat membantu dalam mengembangkan sebuah usaha yang diberikan khususnya dapat meningkatkan perekonomian masyarakat. Hal tersebut disampaikan oleh salah satu penerima bantuan modal usaha yang peneliti

22 Isriawan, Pedagang Kios atau Penerima Bantuan Modal Usaha PNPM Mandiri Desa Lakea II, Wawancara, pada tanggal 22 Agustus 2017. wawancarai pada saat penelitian mengatakan bahwa :

Bantuan yang diberikan oleh PNPM Mandiri Desa Lakea II, sangatlah membantu kami, dalam hal ini saya sebagai pedagang kain dapat menambah modal usaha guna mengembangkan usaha yang saya jalani saat ini. Tentunya hal tersebut tidak lepas dari sebuah perhatian pemerintah dalam meningkatkan usaha kecil maupun menengah yang dilaksanakan oleh masyarakat. Alhamdulillah dengan modal yang diberikan sampai saat ini usaha yang saya jalani masih berjalan dengan baik $^{23}$

Dengan penjelasan yang diungkapkan oleh penerima bantuan modal usaha yang diberikan oleh PNPM Mandiri Desa Lakea II dapat disimpulkan bahwa sampai saat ini efektifitas pemberian modal usaha berjalan dengan baik. Tentunya ini sangat berdampak baik bagi para pengusaha UMKM yang ada di Desa Lakea II.

\subsection{Kendala-kendala yang dihadapi PNPM mandiri}

Walaupun dengan adanya program PNPM mandiri Pedesaan ini sangat membantu masyarakat terutama para pelaku UMKM di Desa Lakea II Kecamatan Lakea, namun ada beberapa kendala yang terjadi yangmenyebabkan kurang

${ }^{23}$ Uja, Pedagang Kios atau Penerima Bantuan Modal Usaha PNPM Mandiri Desa Lakea II, Wawancara, pada tanggal 22 Agustus 2017. 
tercapainyakesejahteraan dan kemandirian bagi masyarakat terutama para pelaku UMKM untuk peningkatan usaha yang telah mereka jalankan. Adapun kendala- kendala tersebutadalah :

a. Karena kurangnya keaktifan masyarakat terutama para pelakuUMKM dalam mengikuti pelatihan dan Musyawarah Antar Desa (MAD) yang diagendakan PNPM Mandiri Pedesaan. Ketika Musyawarah Antar Desa (MAD) inidilaksanakan, menurut pengelola PNPM mandiri Pedesaan masih ada sebagian masyarakatyangtidak ikut serta/berpartisifasi mengikutinya khusunya para pelaku UMKM.

Dalam pelaksanaan Musyawarah Antar Desa (MAD) ini, biasanya pengelola PNPM Mandiri Pedesaan bersama masyarakat akan membahas tentang usulankegiatan yang nantinya akan dilaksanakan sesuai dengan anggaran yang ada di PNPMMandiri Pedesaan. Kegiatan Musyawarah ini biasanya dilaksanakan di Kantor Camat.

Menurut Wati selaku ketua UPK PNPM Mandiri Pedesaan Desa Lakea II Kecamatan Lakea mengatakan bahwa :

Setiap diadakannya kegiatan Musyawarah Antar Desa (MAD) ini, masih ada juga beberapa masyarakat khusunya para pelaku UMKM yang ada di Desa Lakea II yang ikut berpartisifasi mengikutinya, dikarenakan ada beberapa hal sehingga para pelaku usaha UMKM tidak dapat ikut serta dalam Musyawarah Antar Desa (MAD). Tetapi hampir sebagian besar masyarakat ikut serta dalam kegiatan ini. ${ }^{24}$

b. Terdapat beberapa masyarakat yang masih kurangnya kesadaran masyarakat dalam memanfaatkan dana dari program PNPM MandiriPedesaan ini untuk meningkatkan dan mengembangkan usahayang telah mereka jalankan. Dalam hal ini pengembalian modal usaha dalam bentuk simpan pinjam.

Kendala yang kedua ini terjadi karena kebanyakan masyarakat menganggapbahwa untuk mendapatkan dana pinjaman dari PNPM Mandiri Pedessaan ini samasusahnya dengan pinjaman yang diajukan di perbankan. Sehingga dengan haltersebut, menyebabkan kurangnya kesadaran masyarakat untukmemanfaatkan dana pinjaman di PNPM Mandiri Pedesaan ini.

Menurut Bapak Le'o yang merupakan sekretaris PNPM Mandiri Desa Lakea II, mengatakan bahwa :

Ada beberapa masyarakat menganggap bahwa pemberian modal usaha ataupun pinjaman modal usaha yang diberikan oleh PNPM Mandiri sangat rumit

24 Wati, UPK PNPM Mandiri Desa Lakea II Kecamatan Lakea,.Wawancara, pada tanggal 19 Agustus 2017 
atau sama halnya dengan melakukan peminjaman padaBank-bank. ${ }^{25}$

\subsection{Tinjauan Ekonomi Islam Terhadap PNPM Mandiri}

Islam adalah agama yang tidak sempit terhadap perubahan dan perkembanganzaman, artinya segala perubahan dan perkembangan yang terjadi itu dapat di akomodirdengan catatan semua itu tidak bertentangan dengan syariat agama Islam. Terlebih lagipada saat sekarang ini, duna usaha semakin maju dan berkembang sehingga hal itumengakibatkan tuntutan bagi umat Islam untuk menetapkan kejelasan status hukumnya, sebab terkadang permasalahan yang terjadi tidak dijelaskan secaraterperinci.

Islam juga sangat menganjurkan supaya kita senantiasa untuk berusaha danbekerja untuk mendapatkan rezki dari Allah Swt. Karena rezki itu tidak mungkinakan turun dengan sendirinya tanpa ada usaha kita untuk mendapatkannya. Ajaranagama kita yang mulia ini juga telah mengajarkan bahwa Allah Swt tidak akanmungkin merubah nasib suatu kaum atau masyarakat, hingga kaum atau masyarakatitu sendiri yang berusaha untuk merubahnya.

25 Syahrianto, Sekretaris PNPM Mandiri Desa Lakea II Kecamatan Lakea, Wawancara, pada tanggal 21 Agustus 2017

\section{KESIMPULAN DAN SARAN}

Dari hasil penjabaran penelitian yang dilakukan dapat diambil kesimpulanbahwa :

1. Dari beberapa program yang ada di PNPM Mandiri Desa Lakea II yang mempunyai peranan langsung terhadap peningkatanUMKM atau para pelaku Usaha yang ada di Desa Lakea II yaitu dengan menggunakan dua sistem kerj, yaitu pemberian modal usaha secara tunai brdasarkan kriteria tertentu serta memberikan pinjaman modal usaha kepada para pelaku UMKM di Desa Lakea II. Karena dengan adan tambahan modal yang diberikan oleh PNPM Mandiri tentunya dapat mengembangkan usaha-usaha mereka dalam hal ini para pelaku Usaha yang ada di Desa Lakea II.

2. Dengan adanya penambahan modal usaha yang diberikan oleh PNPM Mandiri Desa Lakea II sangat berdampak positif bagi para pelaku usaha di Desa Lakea II. Hal tersebut sangatlah efektif dalam guna mengembangkan usaha mereka dengan dibuktikan terdapat beberapa pealku usaha dalam berkembang dengan baik sampai dengan sekarang ini. Hal ini pula tidak terlepas dari peran aktif pemerintah setempat khususnya pemerintah Desa Lakea II, dalam mengawasi pemberian modal 
usaha terhadap pengguna UMKM yang ada di masyarakat Desa Lakea II dapat memberikan dampak positif tersendiri dalam mengelola lebih efektif penggunaan modal usaha tersebut

3. Sedangkan kendala yang di hadapi oleh PNPM Mandiri yakni masih ada beberapa pelaku usaha belum bisa memanfaatkan program PNPM Mandiri Desa Lakea II dalam hal ini untuk mengembangakan Usaha Mikro Kecil Menengah (UMKM0 di Desa Lakea, hal ini dikarenakan ada beberapa kendala yang mengganjal di benak mereka salah satunya adalah bahwa mereka berfikir dalam peminjaman modal usaha yang diberikan oleh PNPM Mandiri sama saja dengan proses yang ada pada Bank-bank. Dan mereka mengganggap hal tersebut sangatlah rumit bagi mereka.

Saran

1. Kiranya Pemerintah dapat lebih meningkatkanUMKM atau para pelaku Usaha yang ada di Desa Lakea II yaitu dengan menggunakan guna dalam mengembangkan usaha-usaha yang mereka lakukan demi memperoleh hasil perekonomian yang maksimal.

2. Kiranya pemerintah dapat lebih meningkatkan lagi pemberian modal usaha terhadapa pelaku UMKM yang ada di Inodnesia lebioh khusus para pelaku
UMKM yang ada di Desa Lakea II, Tentunya hal ini sangat membantuk perkembangan usaha mereka.

\section{DAFTAR PUSTAKA}

Arikunto, Suharsimi,Prosedur Penelitian Suatu Pendekatan Praktik, Jakarta: PT Rineka Cipta, 2010,

Cahyono, Bambang Tri.Masalah Petani Gunem. Libery. Jogyakarta. 1993,

Departemen Agama RI, Al - Qur'an dan Terjemahannya, Surabaya: CV. Karya Utama, 2005.

Departemen Dalam Negeri Republik Indonesia. Pto, Petunjuk Teknis Operasional Program Nasional Pemberdayaan Masyarakat (Pnpm) Mandiri Perdesaan. Jakarta: Tim Koordinasi Pnpm Mandiri Perdesaan. 2008,

Departemen Pendidikan dan Kebudayaan,Kamus Besar Bahasa Indonesia,Jakarta: Balai Pustaka, 1994,

Ginanjar, Kartasasmita,Pembangunan Untuk Rakyat: MemadukanPertumbuhan Dan Pemerataan. Jakarta: Pustaka Cidesindo. 1996,

Hamid. Rekaman dari Seminar. Dalam Kredit Pedesaan di Indonesia. Mubyarto dan Edy Suandi Hamdi (EDS). Yogyakarta: BPFE, 1986.

Ibu Yahya Muhammad ibn Shumadih atTujibiy, Mukhtashar min Tafsir alImam at-Thabariy, (Kairo: tt), Dar alManar lin-Nasyr wa at-Tauzi'.

Lembaga Ketahanan Nasional,Pembangunan Nasional. (Jakarta: Balai Pustaka).1997. 
Lexy J. Moleong,Metodologi Penelitian Kualitatif, Bandung,: Remaja Rosdakarya.2002,

Muhammad

Hambali, https://marx83.wordpress.com/2008/ 07/05/upaya penanggulangankemiskinan/. Diakses pada 02 Juli 2017, jam 20.33 wita.

Materi Grand Strategi Nasional PNPM Mandiri Pedesaan. Jakarta.

Maeswara, Garda. Biografi Politik Susilo Bambang Yudhoyono. Yogyakarta: Penerbit Narasi. .2009.
Maeswara, Garda.Biografi Politik Susilo Bambang Yudhoyono. (Yogyakarta: Penerbit Narasi. 2009,

Mubyarto. Ekonomi Rakyat IDT dan Demokrasi Ekonomi Indonesia. Yogyakarta: Aditya Media.1994,

Moeljarto.Pemberdayaan Masyarakat. Jakarta: Rineka Cipta,1993,

Ninik Sudarwati. Kebijakan Pengentasan Kemiskinan: Mengurangi Kegagalan Penanggulangan Kemiskinan. Malang: Intimedia 